\title{
Cuba's Aging and Alzheimer Longitudinal Study
}

\author{
Juan de Jesús Llibre-Rodríguez MD PhD DrSc, Adolfo Valhuerdi-Cepero MD MS, Ana M. López-Medina MD MS, \\ Lisseth Noriega-Fernández MD MS, Rutbeskia Porto-Álvarez MD MS, Milagros A. Guerra-Hernández MD MS, \\ Rodolfo I. Bosch-Bayard MD MS, Tania Zayas-Llerena, Elaine Hernandez-Ulloa, Ana L. Rodríguez-Blanco MD MS, \\ Enrique Salazar-Pérez, Juan C. Llibre-Guerra MD MS, Jorge J. Llibre-Guerra MD MS, Beatriz Marcheco-Teruel MD PhD
}

\begin{abstract}
Aging and Alzheimer is a prospective, longitudinal cohort study involving 2944 adults aged $\geq 65$ years from selected areas in Cuba's Havana and Matanzas Provinces. This door-to-door study, which began in 2003, includes periodic assessments of the cohort based on an interview; physical exam; anthropometric measurements; and diagnosis of dementia and its subtypes, other mental disorders, and other chronic non-communicable diseases and their risk factors. Information was gathered on sociodemographic characteristics; disability, dependency and frailty; use of health services; and characteristics of care and caregiver burden. The first assessment also included blood tests: complete blood count, blood glucose, kidney
\end{abstract}

and liver function, lipid profile and ApoE4 genotype (a susceptibility marker). In 2007-2011, the second assessment was done of 2010 study subjects aged $\geq 65$ years who were still alive. The study provides data on prevalence and incidence of dementia and its risk factors, and of related conditions that affect the health of older adults. It also contributes valuable experiences from field work and interactions with older adults and their families. Building on lessons learned, a third assessment to be done in 2016-2018 will incorporate a community intervention strategy to respond to diseases and conditions that predispose to dementia, frailty and dependency in older adults.

KEYWORDS Dementia, Alzheimer disease, chronic disease, aging, chronic illness, frailty, dependency, cohort studies, Cuba

\section{INTRODUCTION}

From 2000 to 2050, the number of people aged $\geq 60$ years will increase from 600 million to 2 billion, and by 2050 will make up $22 \%$ of the world's population. Four fifths of these older adults will live in Asia, Africa and Latin America.[1] Population aging is associated with the current epidemic of chronic diseases, explaining their greater disease burden in these regions.[2,3]

According to the World Alzheimer Report 2016 there were 47 million people living with dementia,[4] and the World Alzheimer Report 2015 estimated 9.9 million new cases every year.[5] In $2001,60 \%$ of persons with dementia were living in developing countries, and this percentage is predicted to increase to $71 \%$ by 2040 . Currently, 1.8 million people in Latin America have dementia, and the number is expected to climb to 4.1 million by 2020 and 9.1 million by 2040 - similar to the number of people with dementia in the USA and Canada predicted for 2040.[5]

Dementia is responsible for $11.2 \%$ of years lived with disability in persons aged $\geq 60$ years, a higher percentage than cerebrovascular disease $(9.5 \%)$, musculoskeletal diseases $(8.9 \%)$, cardiovascular disease $(5.0 \%)$ and cancer (2.4\%).[3] Furthermore, the annual cost of caring for people with dementia is estimated to be 818 billion dollars worldwide; $70 \%$ of these expenditures will be in the USA, Canada and Europe.[6] The enormous costs of dementia and the challenge posed by increasing numbers of older adults will lead to substantial changes in health care systems around the world. As the number of people with dementia is doubling every 20 years,[5] costs can be expected to increase proportionally. However, the greatest cost of dementia is human, and its dimensions are inestimable.

Cuba is currently the "oldest" country in Latin America, with $2,180,000$ persons aged $\geq 60$ years, just over $19 \%$ of its population in 2015 . This proportion will grow to $25 \%$ by 2020 , when it is projected that 400,000 people will be aged $\geq 80$ years.[7]
Longitudinal studies facilitate investigation of determinants of life expectancy, risk factors for chronic diseases and states such as dependency and frailty, and their association with mortality. There is growing interest in studying frailty and its risk factors, due to its importance for designing preventive interventions to alter the processes of aging, dependency and mortality.

Aging and Alzheimer is a prospective, longitudinal study of 2944 older Cuban adults, two phases of which have been completed.

The study began in 2003, with the purpose of (a) ascertaining the prevalence and incidence of dementia and its most frequent type, Alzheimer disease, (b) identifying risk factors for dementia and their association with other chronic non-communicable diseases in this age group (cerebrovascular disease, diabetes, hypertension), and (c) doing an in-depth study of their risk and genetic markers, and their impact in terms of needs for care, disability and caregiver psychological morbidity. The project also contemplates a third phase to learn about trends in dementia and evaluate the impact of a community intervention strategy, for which the first two phases have laid the statistical and operational groundwork.

This article describes lessons learned in the Aging and Alzheimer longitudinal study, begun in 2003, starting with its planning and design. The study has revealed the high prevalence of dementia in Cuba, its risk factors and its consequences in terms of caregiver burden and need for care. It also describes experiences that lay the groundwork for design and implementation of a community intervention strategy.

\section{INTERVENTION}

Study design Aging and Alzheimer is a prospective cohort study involving 2944 adults aged $\geq 65$ years. Methodology and design are detailed in other publications.[8,9] The study involved participation of primary, secondary and tertiary health institutions; health professionals from various specialties, including medical 
and psychology students; and volunteers, groups and family associations that helped to recruit and encourage participants and their families.

Of the 2944 participants in the study, 2043 came from seven Havana Province polyclinic health areas and 901 from Milanés Polyclinic in the city of Matanzas. Polyclinics are primary health care institutions to which a number of family doctor-and-nurse offices report and that provide services in primary care specialties, including pediatrics, gynecology, psychiatry, internal medicine, psychology, rehabilitation, imaging, clinical laboratory and dentistry.[10] Participating polyclinics in Havana Province (municipality in parentheses) were: 19 de Abril (Plaza); Ana Betancourt (Playa); Cristóbal Labra (La Lisa); 27 de Noviembre, Ramón González Coro and José M. Portuondo (all in Marianao); and 14 de Junio Polyclinic (10 de Octubre).

Instruments The assessment protocol was based on the 10/66 Dementia Research Group questionnaire involving a structured interview covering sociodemographic characteristics, health status, lifestyles and risk factors;[8,9] a physical exam, which included a neurological study; and an interview with a reliable informant (who, in the judgment of the family and surveyor, best knew the participant, and who in most cases was a relative living in the home, and the primary caretaker). All materials, questionnaires and assessments had been previously validated to permit their utilization in populations with different cultures and educational levels. The final version was reviewed by a steering committee (project head and principal investigators for content areas). A procedural manual and a training video for physical and neurological exams were prepared. In each phase, all researchers and participants from the health area received an intensive one-week training given by the senior researcher on use of the instruments and surveys. Instruments were administered by these trained medical specialists, with support from psychology and medical students.[9]

Interviews and questionnaire administration were done in participants' homes, lasting an average of $1 \frac{1}{2}-2$ hours. A specialist in the research group reviewed $5 \%$ of interviews, randomly selected, for quality control. Interviews and physical exams were done in a single visit. Table 1 shows the main variables and instruments used in the two previous assessments and for the assessments to be done in 2016-2018, incorporating lessons learned.

Data processing and analysis Interviewers entered questionnaire data and responses in Epidat (version 3.1) software, and then exported the information to SPSS (version 18).
Table 1: Variables and aspects probed in assessments for the Aging and Alzheimer Study, by study phase

\begin{tabular}{|c|c|c|c|}
\hline & $\begin{array}{c}2003- \\
2006\end{array}$ & $\begin{array}{c}2007- \\
2011\end{array}$ & $\begin{array}{l}2016- \\
2018^{*}\end{array}$ \\
\hline \multicolumn{4}{|l|}{ Sociodemographic characteristics } \\
\hline Age, sex, marital status, educational level & $\mathrm{x}$ & $\mathrm{x}$ & $\mathrm{x}$ \\
\hline Housing conditions & $x$ & $\mathrm{x}$ & $\mathrm{x}$ \\
\hline $\begin{array}{l}\text { Socioeconomic factors: best occupation (own and spouse's), } \\
\text { current occupation, income amount and sources, housing } \\
\text { quality and household amenities }\end{array}$ & $\mathrm{x}$ & $\mathrm{x}$ & $\mathrm{x}$ \\
\hline \multicolumn{4}{|l|}{ Information collected in participant interview } \\
\hline Birth and early years & $\mathrm{x}$ & $\mathrm{x}$ & $x$ \\
\hline Current circumstances & $x$ & $x$ & $x$ \\
\hline Social networks & $\mathrm{x}$ & $\mathrm{x}$ & $\mathrm{x}$ \\
\hline Socioeconomic status & $\mathrm{x}$ & $\mathrm{x}$ & $\mathrm{x}$ \\
\hline $\begin{array}{l}\text { Morbidity (dementia, diabetes mellitus, cerebrovascular } \\
\text { disease, hypertension, ischemic heart disease, depression), } \\
\text { according to established criteria }\end{array}$ & $\mathrm{x}$ & $\mathrm{x}$ & $\mathrm{x}$ \\
\hline Disability (WHODAS-II) and dependency[11] & $\mathrm{x}$ & $\mathrm{x}$ & $\mathrm{x}$ \\
\hline Reproductive health & $x$ & $\mathrm{x}$ & $\mathrm{x}$ \\
\hline Unhealthy habits, nutrition and lifestyles & $\mathrm{x}$ & $\mathrm{x}$ & $x$ \\
\hline Health service utilization & $x$ & $x$ & $x$ \\
\hline Quality of life (DEMQOL)[12] & & $x$ & $x$ \\
\hline \multicolumn{4}{|l|}{ Cognitive function } \\
\hline CSI'D’[13] & $\mathrm{x}$ & $\mathrm{x}$ & $\mathrm{x}$ \\
\hline 10-word recall test (CERAD)[14] & $x$ & $x$ & $x$ \\
\hline Mental health (GMS-version B3)[15] & $x$ & $x$ & $x$ \\
\hline \multicolumn{4}{|l|}{ Physical exam } \\
\hline Neurological exam & $\mathrm{x}$ & $\mathrm{x}$ & $\mathrm{x}$ \\
\hline $\begin{array}{l}\text { Physical assessment (anthropometric measurements, weight, } \\
\text { height, pulse/blood pressure) }\end{array}$ & $\mathrm{x}$ & $x$ & $x$ \\
\hline Cerebrovascular disease assessment & $x$ & $\mathrm{x}$ & $\mathrm{x}$ \\
\hline $\begin{array}{l}\text { Frailty assessment } \\
\text { (dynamometry, spirometry) }\end{array}$ & & & $x$ \\
\hline Vision, hearing & & & $\mathrm{x}$ \\
\hline \multicolumn{4}{|l|}{ Biological assessment } \\
\hline $\begin{array}{l}\text { Hematology, whole blood count (hemoglobin, hematocrit, } \\
\text { differential, MCV, MCH, MCHC) }\end{array}$ & $\mathrm{x}$ & $\mathrm{x}$ & $x$ \\
\hline $\begin{array}{l}\text { Blood biochemistry (fasting blood sugar, cholesterol and } \\
\text { fractions, triglycerides, albumin, total protein, thyrotropin) }\end{array}$ & $\mathrm{x}$ & $\mathrm{x}$ & $\mathrm{x}$ \\
\hline Genotype (ApoE4) & $\mathrm{x}$ & & $\mathrm{x}$ \\
\hline Biomarkers of aging (cytokines, telomere length, testosterone) & & & $x$ \\
\hline \multicolumn{4}{|l|}{ Information collected in caregiver-informant interview } \\
\hline Participant background & $\mathrm{x}$ & $\mathrm{x}$ & $x$ \\
\hline Caregiver questionnaire & $x$ & $x$ & $\mathrm{x}$ \\
\hline CSI'D', informant section[13] & $x$ & $x$ & $x$ \\
\hline HAS-D[16] & $x$ & $x$ & $\mathrm{x}$ \\
\hline Psychological and behavioral symptoms of dementia (NPI)[17] & $x$ & $x$ & $\mathrm{x}$ \\
\hline Quality of life (DEMQOL)[12] & & $x$ & $\mathrm{x}$ \\
\hline Verbal autopsy & & $\mathrm{x}$ & $x$ \\
\hline $\begin{array}{l}\text { *Measurements to be considered in the } 2016-2018 \text { assessment } \\
\text { CERAD: The Consortium to Establish a Registry for Alzheimer's Disease } \\
\text { CSI'D': Community Screening Instrument for Dementia } \\
\text { DEMQOL: Dementia quality of life questionnaire } \\
\text { GMS: Geriatric Mental State Examination } \\
\text { HAS: History and Aetiology Schedule } \\
\text { MCH: mean corpuscular hemoglobin } \\
\text { MCHC: mean corpuscular hemoglobin concentration } \\
\text { MCV: mean cell volume } \\
\text { NPI: Neuropsychiatric Inventory } \\
\text { WHODAS: World Health Organization Disability Assessment Schedule }\end{array}$ & & & \\
\hline
\end{tabular}


Ethics The study protocol was approved by the Medical University of Havana's Ethics Committee and by those of each polyclinic. During home visits, participants and their families received information sheets that explained the study, benefits of participation, absence of risk, and data confidentiality, and assured them that they could withdraw from the study at any time without affecting relations with their health care team. Once so informed, participants and family members provided written consent.

\section{LESSONS LEARNED}

To our knowledge, the Aging and Alzheimer project is the largest longitudinal study of older adults in the Cuban population. It has produced estimates of prevalence, incidence and risk factors for dementia and associated comorbidities (including cerebrovascular disease, diabetes mellitus, ischemic heart disease and hypertension), and conditions such as frailty, disability and dependency.

Sociodemographic characteristics and results of the first assessment done in 2003-2006 of 2944 participants have been published.[9,18] Using 10/66 criteria, prevalence of dementia syndrome in adults aged $\geq 65$ years was estimated to be $10.8 \%$ (women $11.6 \%, 95 \%$ Cl 10.3\%-13.1\%; men 9.2\%, 95\% Cl 7.6\%-11.2\%). Using DSMIV criteria, overall prevalence was estimated to be $6.4 \%$ (women $7.1 \%, 95 \%$ Cl 6.1\%-8.4\%; men 5.2\%, 95\% Cl 4.0\%-6.7).

Alzheimer disease is the most frequent cause of dementia, followed by vascular dementias. Age-specific DSM-IV prevalence rates are slightly higher in Cuba (with an age- and sex-standardized morbidity ratio of 1.08 ) than those reported in the EURODEM study, a meta-analysis of 14 European studies.[18]

Prevalence of chronic non-communicable diseases in participating older adults is high (Table 2); in decreasing order of frequency, they are: hypertension, diabetes mellitus, ischemic heart disease, dementia

Table 2: Chronic non-communicable diseases and other health conditions in the first assessment

\begin{tabular}{|l|r|}
\hline & \multicolumn{1}{|c|}{$\mathbf{n ~ ( \% )}$} \\
\hline Population aged $\geq 65$ years & 2944 \\
\hline Chronic diseases and other health conditions \\
\hline Dementia & $320(10.9)$ \\
\hline Diabetes mellitus & $543(18.4)$ \\
\hline Cerebrovascular disease & $230(7.8)$ \\
\hline Hypertension & $2144(72.8)$ \\
\hline Ischemic heart disease & $415(14.1)$ \\
\hline Depression & $144(4.9)$ \\
\hline Need for care & $187(6.4)$ \\
\hline Frailty & $635(21.6)$ \\
\hline Anemia (MD = 589) & $449(19.1)$ \\
\hline Comorbidities (MD = 7) & $1266(43.1)$ \\
\hline O & $1380(47.0)$ \\
\hline 1-2 & $291(9.9)$ \\
\hline$\geq 3$ & $1620(55.2)$ \\
\hline Risk factors & $105(3.6)$ \\
\hline Smoking (current or former) (MD = 11) & $1063(36.4)$ \\
\hline At-risk drinking (MD = 9)
\end{tabular}

MD: missing data and cerebrovascular disease. A little over one-fifth of patients were diagnosed as frail, $19.1 \%$ were anemic and $6.4 \%$ needed care most of the time; $56.9 \%$ of interviewees had $\geq 1$ illness.[19]

In 2007-2011 a second assessment was done of the cohort, composed of 2010 surviving participants from the first assessment who gave their consent, with 4.1 years of followup. Annual dementia incidence was 21.2 per 1000 population aged $\geq 65$ years. Dementia was associated with different risk factors, in particular: advanced age (RR 1.79, 95\% Cl 1.37\%-2.39\%), hypertension (RR 1.35, 95\% Cl 1.02\%-2.37\%), cerebrovascular disease (RR $2.84,95 \% \mathrm{Cl} 1.20 \%-6.72 \%$ ), carrying one or two alleles of the ApoE4 gene (RR 1.93, 95\% Cl 1.03\%-3.81\%), Parkinsonian signs (RR 1.18, 95\% Cl 1.05\%-1.33\%) and mild cognitive impairment (RR 2.21, 95\% Cl 1.12\%-4.93\%). Higher educational level was a protective factor (RR 0.77, 95\% Cl 0.67\%-0.98\%).[18] Dementia incidence was similar to that reported by the Canadian Study of Health and Aging, the most extensive longitudinal study of adults aged $\geq 65$ years in the world, which reported an annual incidence of 21.8 per 1000 women and 19.1 per 1000 men.[20]

In 2011-2013, the study analyzed, among other variables, frailty and dependency associated with dementia and other chronic diseases of aging, as well as mortality. Prevalence of frailty syndrome was $21.6 \%(95 \% \mathrm{Cl} 17.9 \%-23.8 \%)$. This syndrome was associated with increasing age, anemia and comorbidity. Incidence of dependency was 33.1 per 1000 population/year (95\% Cl 29.1\%-37.6\%) and mortality was 55.1 per 1000 population/year. Advanced age, male sex, lower lifetime occupational status, dependency, frailty syndrome, dementia, depression, cerebrovascular disease and diabetes were associated with higher risk of death.[21]

More than any other physical or mental illness, dementia has two important consequences that in turn have a social impact on older adults: need for care, and family members being obliged to stop working to assume the caregiver role. It is also the source of great psychological strain on caregivers.[18]

One limitation of the study is that its results cannot be generalized to all of Cuba. However, the strategy of surveying the entire population in selected areas increases the response rate (above 95\% for both the first and second assessments) and facilitates longitudinal followup. Having specialized personnel administer a standardized questionnaire in a single visit is a strength of the study. This protocol was validated for the Cuban population and case followup confirmed reliability and validity of the diagnosis and information obtained.[19] This enabled us to obtain detailed information on participants' physical and mental health, risk factors, need for care and impact on families and on society.

The results have contributed to better knowledge of dementia and associated comorbidity patterns in the older adults, at a time when we are seeing accelerated demographic aging and an epidemiological transition in Cuba. They imply the urgent need to implement intervention and prevention strategies for various agerelated conditions, in particular, disability, frailty and dependency. The demonstration of feasibility and validity of a design free of transcultural or educational bias in a one-phase diagnostic protocol for epidemiological studies of dementias is unprecedented in Cuba.

Furthermore, having evidence of the number of ill people in a community and the impact this has, has raised awareness among 
the public and policymakers responsible for addressing this growing health problem.

The study demonstrates that levels of stress and burden on caregivers of people with dementia are as high as those typically reported in developed countries, despite strong traditions and extended families in Cuban society.[19] A five-session education and training intervention program for caregivers has been developed, particularly useful because it can be taught by nurses, medical students and social workers; it is expected to be validated in phase three of the study.

Cognitive stimulation therapy for people with mild cognitive impairment and early-stage dementia has been provided as part of these population studies. Also, as part of the project, two university extension programs were created (the Alois Alzheimer Program at the Medical University of Havana and the "Healthy Mind in a Healthy Body" Integration program at the Medical University of Matanzas) that link students to research and community intervention not only for dementias, but also for other frequent diseases and conditions of aging, including their prevention, early diagnosis and help for families.

As a result of lessons learned, a third assessment will be conducted in 2016-2018, in the same study areas. Using a new census, 3000 persons aged $\geq 65$ years will be selected, including earlier study participants who are still alive. The protocol will be similar to the one used for the preceding assessments, with the addition of tests to diagnose frailty syndrome (dynamometry, spirometry), along with blood sampling for supplementary testing and detection of biological markers for dementia, frailty and immunosenescence. The objective of the study's third phase is to learn about changes in dementia prevalence a decade after the baseline study and to provide more in-depth study of conditions such as frailty and dependency and their relationship to Cuba's demographic aging and health transition.

Another lesson learned is the need to evaluate the effectiveness of a community intervention strategy for primary health care for frail and dependent older adults, to address illnesses and conditions that predispose to dementia, frailty and dependency in older adults. This is why older adults diagnosed as frail and dependent will receive a care program. This will be a horizontal intervention delivered by nurses and nonprofessional health workers (including medical students) under the supervision of primary care physicians. It will target disabilities (immobility/ inactivity syndrome, malnutrition, incontinence, impaired vision and hearing, behavioral symptoms and depression) that coexist with other comorbidities and chronic non-communicable diseases. - M

\section{REFERENCES}

1. United Nations Department of Economic and Social Affairs (UNDESA), Population Division. World Population Prospects: the 2012 Revision. Highlights and Advanced Tables. Working Paper No. ESA/P/WP/. 228. New York: United Nations; 2013. 94 p.

2. Abegunde DO, Mathers CD, Adam T, Ortegon M Strong K. The burden and costs of chronic diseases in low-income and middle-income countries. Lancet. 2007 Dec 8:370(9603):1929-38.

3. Prince $M J$, Wu F, Guo $Y$, Gutiérrez Robledo LM, O'Donnell M, Sullivan $R$, et al. The burden of disease in older people and implications for health policy and practice. Lancet. $2015 \mathrm{Feb}$ 7;385(9967):549-62.

4. Alzheimer's Disease International. World Alzheimer Report 2016_Improving healthcare for people living with dementia: Coverage, quality and costs now and in the future [Internet]. London: Alzheimer's Disease International; 2016 [cited 2016 Sep 20]. 140 p. Available from: http:// www.alz.co.uk/research/world-report-2016

5. Prince M, Wimo A, Guerchet M, Ali GC, Wu YT, Prina M. World Alzheimer Report 2015. The Global Impact of Dementia. An analysis of prevalence, incidence, cost and trends [Internet]. London: Alzheimer's Disease International; 2015 Aug [cited 2016 Sep 20]. 92 p. Available from: http://www.alz.co.uk/research/world-report-2015

6. Wimo A, Prince M. World Alzheimer Report 2010: The Global Economic Impact of Dementia [Internet]. London: Alzheimer's Disease International; 2010 [cited 2016 Sep 17]. Available from: http://www.alz.co.uk/research/world-report-2010

7. National Health Statistics and Medical Records Division (CU) [Internet]. Anuario Estadístico de Salud 2015. Havana: Ministry of Public Health (CU); 2015 [cited 2016 Apr 25]. 208 p. Available from: http://files.sld.cu/dne/2016/04/07/anuario -estadistico-de-salud-2015/. Spanish.

8. Prince M, Ferri CP, Acosta D, Albanese E, Arizaga R, Dewey M, et al. The protocols for the 10/66 Dementia Research Group population-based research programme. BMC Public Health. 2007 Jul 20;7:165.

9. Llibre Rodríguez JJ, Ferri CP, Acosta D, Guerra M, Huang Y, Jacob KS, et al. Prevalence of dementia in Latin America, India, and China: a population-based cross-sectional survey. Lancet. 2008 Aug 9;372(9637):464-74.

10. Gorry C. Primary care forward: raising the profile of Cuba's nursing profession. MEDICC Rev. 2013 Apr;15(2):5-9.

11. Rehm J, Ustun TB, Saxena S, Nelson CB, Chatterji $S$, Ivis $F$, et al. On the development and psychometric testing of the WHO screening instrument to assess disablement in the general population. Int J Methods Psychiatric Res. 1999 Jun;8(2):110-22.

12. Smith SC, Lamping DL, Banerjee S, Harwood R, Foley B, Smith P, et al. Measurement of healthrelated quality of life for people with dementia: development of a new instrument (DEMQOL) and an evaluation of current methodology. Health Technol Assess. 2005 Mar;9(10):1-93.

13. Hall KS, Hendrie HH, Brittain HM, Norton JA, Rodgers DD, Prince CS. The development of a dementia screening interview in two distinct languages. Int $\mathrm{J}$ Methods Psychiatric Res. 1993;3:1-28.

14. Morris JC, Heyman A, Mohs RC, Hughes JP, van Belle G, Fillenbaum G, et al. The Consortium to Establish a Registry for Alzheimer's Disease (CERAD). Part I. Clinical and neuropsychological assessment of Alzheimer's disease. Neurology. 1989 Sep;39(9):1159-65.

15. Copeland JRM, Dewey ME, Griffith-Jones HM. A computerized psychiatric diagnostic system and case nomenclature for elderly subjects: GMS and AGECAT. Psychol Med. 1986 Feb;16(1):89-99.

16. Dewey ME, Copeland JR. Diagnosis of dementia from the history and aetiology schedule. Int J Geriatr Psychiatry. 2001 Sep;16(9):912-7.

17. Kaufer DI, Cummings JL, Ketchel $P$, Smith V, MacMillan A, Shelley T. Validation of the NPI-Q, a brief clinical form of the Neuropsychiatric In- ventory. J Neuropsychiatry Clin Neurosci. 2000 Spring;12(2):233-9.

18. Llibre Rodríguez JJ, Valhuerdi A Sánchez II, Reyna C, Guerra MA, Copeland JRM, et al. The prevalence, correlates and impact of dementia in Cuba. A 10/66 Group population-based survey. Neuroepidemiology. 2008;31(4):243-51.

19. National Council of Scientific Societies (CU). Libro Premio Anual de la Salud, 2011. 36th ed [Internet]. Havana: Editorial Ciencias Médicas; 2012 [cited 2016 Sep 15]. Chapter, Categoría Investigación Aplicada. Prevalencia, incidencia y factores de riesgo de síndrome demencial en adultos mayores de La Habana y Matanzas. p. 54-65. ISBN: 978-959-212-778-4. Available from: http://www.bvs.sld.cu/libros/premio_anual 2011/emplane\%20premio\%202011_completo .pdf. Spanish.

20. The incidence of dementia in Canada The Canadian Study of Health and Aging Working Group. Neurology. $2000 \mathrm{Jul}$ 12;55(1):66-73.

21. Llibre JJ, López AM, Valhuerdi A, Guerra M, Llibre-Guerra JJ, Sánchez YY, et al. Frailty, dependency and mortality predictors in a cohort of Cuban older adults, 2003-2011. MEDICC Rev. 2014 Jan;16(1):24-30.

\section{THE AUTHORS}

Juan de Jesús Llibre-Rodríguez (Corresponding author: mguerra@infomed.sld.cu), internist with a doctorate in medical sciences and advanced doctorate in science. Full professor and senior researcher, Alzheimer Studies Center, Finlay-Albarrán Faculty of Medical Sciences, Medical University of Havana (UCMH), Cuba.

Adolfo Valhuerdi-Cepero, internist with a master's degree in emergency medicine. Assistant professor, Faustino Pérez ClinicalSurgical University Hospital, Matanzas, Cuba. 
Ana M. López-Medina, physician with dual specialties in family medicine and geriatrics \& gerontology; and a master's degree in healthy aging. Assistant professor, Héroes del Corynthia University Polyclinic, Havana, Cuba.

Lisseth Noriega-Fernández, psychiatrist with a master's degree in healthy aging, Marianao Mental Health Center, Havana, Cuba.

Rutbeskia Porto-Álvarez, physician specializing in intensive care with a master's degree in emergency medicine. Assistant professor, Faustino Pérez Clinical-Surgical University Hospital, Matanzas, Cuba.

Milagros A. Guerra-Hernández, psychiatrist with a master's degree in healthy aging. Assistant professor, 27 de Noviembre University Polyclinic, Marianao, Havana, Cuba.
Rodolfo I. Bosch-Bayard, internist with a master's degree in aging and public health. Associate professor, Finlay-Albarrán Faculty of Medical Sciences, UCMH, Havana, Cuba.

Tania Zayas-Llerena, information management specialist. Assistant professor, Finlay-Albarrán Faculty of Medical Sciences, UCMH, Havana, Cuba.

Elaine Hernández-Ulloa, psychologist. Assistant professor, Finlay-Albarrán Faculty of Medical Sciences, UCMH, Havana, Cuba.

Ana L. Rodríguez-Blanco, internist with a master's degree in aging and public health. Associate professor, Cristóbal Labra Polyclinic, Havana, Cuba.

Enrique Salazar-Pérez, nurse, Cristóbal Labra Polyclinic, Havana, Cuba.
Juan C. Llibre-Guerra, neurologist with a master's degree in healthy aging. Associate professor, Neurology and Neurosurgery Institute, Havana, Cuba.

Jorge J. Llibre-Guerra, neurology resident with a master's degree in cerebrovascular disease, Neurology and Neurosurgery Institute, Havana, Cuba.

Beatriz Marcheco-Teruel, clinical geneticist with a doctorate in medical sciences. Full professor, senior researcher and Director, National Medical Genetics Center, UCMH, Havana, Cuba.

Submitted: May 31, 2016

Approved for publication: December 19, 2016 Disclosures: None 